\title{
Sex-specific hormone changes during immunotherapy and its influence on survival in metastatic renal cell carcinoma
}

\author{
Gennadi Tulchiner ${ }^{1} \cdot$ Renate Pichler $^{1} \cdot$ Hanno Ulmer ${ }^{2} \cdot$ Nina Staudacher $^{1} \cdot$ Andrea Katharina Lindner $^{1}$. \\ Andrea Brunner ${ }^{3} \cdot$ Bettina Zelger $^{3} \cdot$ Fabian Steinkohl $^{4} \cdot$ Friedrich Aigner $^{4} \cdot$ Wolfgang Horninger $^{1} \cdot$ Martin Thurnher $^{1} \oplus$
}

Received: 24 July 2020 / Accepted: 1 February 2021 / Published online: 28 February 2021

(c) The Author(s) 2021

\begin{abstract}
Renal cell carcinoma (RCC) is a highly vascularized and immunogenic tumor, being an ideal candidate for checkpoint blockade-based immunotherapy. Accordingly, checkpoint inhibitors have demonstrated clinical efficacy in patients with metastatic RCC (mRCC). Sex-specific differences in cancer immunotherapy may be explained by the interaction of sex hormone signaling, genetic and environmental factors, affecting the innate and adaptive immune response in men and women in different ways. The aim of this prospective study was to monitor for the first time changes in sex hormones including luteinizing hormone (LH), follicle-stimulating hormone (FSH), LH/FSH ratio and 17-ß-estradiol (E2) in $22 \mathrm{mRCC}$ patients (12 male and 10 female) receiving nivolumab therapy. In contrast to female patients, male patients showed a significant increase in $\mathrm{E} 2(p=0.006)$ and LH/FSH ratio $(p=0.013)$ from the beginning of nivolumab therapy to week 12 of follow-up. Moreover, survival analysis revealed a significant negative association between LH/FSH ratio and progression-free survival (PFS) $(p=0.022)$ as well as between therapy response $(p=0.009)$ in males compared to females at interim evaluation (week $6 / 8$ ). Our findings may therefore be the first reference to sex hormone changes during immunotherapy.
\end{abstract}

Keywords Renal cell carcinoma $\cdot$ Checkpoint inhibition $\cdot$ Sex hormones $\cdot$ Estrogen $\cdot$ Luteinizing hormone/folliclestimulating hormone $\cdot$ Immunotherapy

\section{Abbreviations}

AEs Adverse events

ANC Absolute neutrophil count

AUC Area under the curve

CT Computed tomography

$\begin{array}{ll}\text { CR } & \text { Complete remission } \\ \text { DCs } & \text { Dendritic cells } \\ \text { E2 } & 17-\beta \text {-estradiol } \\ \text { ER- } \alpha & \text { Estrogen receptor- } \alpha \\ \text { ER- } \beta & \text { Estrogen receptor- } \beta\end{array}$

Fabian Steinkohl

Fabian.Steinkohl@i-med.ac.at

Friedrich Aigner

Friedrich.Aigner@tirol-kliniken.at

Wolfgang Horninger

Wolfgang.Horninger@i-med.ac.at

Gennadi.Tulchiner@i-med.ac.at

Hanno Ulmer

Hanno.Ulmer@i-med.ac.at

Nina Staudacher

Nina.Staudacher@i-med.ac.at

Andrea Katharina Lindner

Andrea.Lindner@i-med.ac.at

Andrea Brunner

Andrea.Brunner@i-med.ac.at

Bettina Zelger

Bettina.Zelger@i-med.ac.at
1 Department of Urology \& Immunotherapy Unit, Medical University Innsbruck, Anichstrasse 35 and Innrain 66a, 6020 Innsbruck, Austria

2 Department of Medical Statistics, Informatics and Health Economics, Medical University Innsbruck, Schoepfstraße 41, 6020 Innsbruck, Austria

3 Department of Pathology, Medical University Innsbruck, Muellerstraße 44, 6020 Innsbruck, Austria

4 Department of Radiology, Medical University Innsbruck, Anichstrasse 35, 6020 Innsbruck, Austria 


$\begin{array}{ll}\text { FSH } & \text { Follicle stimulating hormone } \\ \text { IFN- } \alpha & \text { Interferon alpha } \\ \text { IL-2 } & \text { Interleukin-2 } \\ \text { IMDC } & \text { International Metastatic RCC Database } \\ & \text { Consortium } \\ \text { IQR } & \text { Interquartile ranges } \\ \text { IV } & \text { Intravenous } \\ \text { KPS } & \text { Karnofsky Performance Status } \\ \text { LH } & \text { Luteinizing hormone } \\ \text { mRCC } & \text { Metastatic renal cell carcinoma } \\ \text { mTOR } & \text { Mammalian target of rapamycin } \\ \text { OR } & \text { Objective response rate } \\ \text { OS } & \text { Overall survival } \\ \text { PD-1 } & \text { Programmed cell death-1 } \\ \text { PD-L1 } & \text { Programmed cell death ligand 1 } \\ \text { PFS } & \text { Progression-free survival } \\ \text { PR } & \text { Partial remission } \\ \text { RCC } & \text { Renal cell carcinoma } \\ \text { ROC } & \text { Receiver operating characteristic } \\ \text { SD } & \text { Stable disease } \\ \text { TILs } & \text { Tumor-infiltrating lymphocytes } \\ \text { TKIs } & \text { Tyrosine kinase inhibitors }\end{array}$

\section{Introduction}

Renal cell carcinoma (RCC) is one of the most immuneresponsive cancers in humans [1]. Immunotherapy with interleukin-2 (IL-2) and/or interferon alpha (IFN- $\alpha$ ) was thought to increase and mobilize tumor-infiltrating lymphocytes (TILs), facilitating tumor regression. However, this form of cytokine-based immunotherapy showed only few durable complete remissions [2-5]. Modified tumor cells [6] or tumor antigen-loaded dendritic cells (DCs) [7] were used to activate antitumor $\mathrm{T}$ cell responses in vivo [1]. DC vaccination, which counts as a personalized treatment modality, was found to induce antigen-specific [7] as well as antigenindependent immune responses [8] and to maintain quality of life [9].

The introduction of immunotherapy in RCC revolutionized cancer therapy with the use of immune checkpoint inhibitors. Nivolumab is a fully human IgG4 antibody specific for PD-1, which blocks suppressive PD-1 signaling induced by its ligands and thereby restores antitumor $\mathrm{T}$ cell immunity [10]. According to the Checkmate 025 study [11], nivolumab was the first immune checkpoint inhibitor that was approved for second line treatment of patients with mRCC based on significantly better overall survival (OS). Furthermore, nivolumab demonstrated a higher objective response rate (ORR), fewer grade 3 or 4 treatment-related adverse events (AEs) and improved quality of life compared with the mTOR inhibitor everolimus [12]. Moreover, nivolumab demonstrated an OS improvement versus everolimus across various subgroups such as: International Metastatic RCC Database Consortium (IMDC) risk groups; age; one, two or more sites of metastases; number and duration of prior therapy; bone, liver and lung metastases and finally the type of prior therapy (sunitinib, pazopanib or IL-2 therapy) [13]. Further, novel combination therapies, such as nivolumab plus ipilimumab (CTLA-4-inhibitor), avelumab (PD-L1-inhibitor) plus axitinib, a tyrosine kinase inhibitor (TKI) and finally pembrolizumab (PD-1-inhibitor) plus axitinib, showed improvement in first-line mRCC therapy [14-17].

In addition to immunogenicity and vascularization, hormone-dependence is another feature of RCC [18]. Although the role of sex hormones in RCC development remains controversial, it is strongly implied by the higher incidence of RCC in males, who are affected twice as often [18]. Sex is a known factor that influences both innate and adaptive immune response [19] including sex-specific differences in immunotherapy response [20]. These findings are corroborated by increasingly reported sex disparities in response to immunotherapy in a variety of tumor types. However, contradictory results have also been reported. No significant correlation between sex and response to immunotherapy could be demonstrated in two recently published metaanalyses that included different cancer types and compared 9322 men with 4399 women [21] and 12,674 men with 7025 women, respectively [22]. On the contrary, other reports showed that female sex is an unfavorable predictive factor for response to immunotherapy [19, 23]. Moreover, a significant survival benefit was reported for men treated with anti CTLA-4 or anti-PD-1 therapies in a large meta-analysis of 20 randomized clinical trials including 11,351 patients with advanced or metastatic cancer [24], whereas the role of gender was examined in these studies and sex hormones have hardly been assessed. Sex hormones are considered responsible for the differences between male and female immune responses. For instance, estrogens are known to increase the production of immunoglobulins [25-27]. Androgens including dihydrotestosterone and testosterone have been reported to suppress immune activity [28]. Regulatory $\mathrm{T}$ cells $\left(\mathrm{T}_{\text {reg }}\right.$ cells) increase with high estrogen and decrease with low estrogen levels [29]. Moreover, low estrogen levels promote $\mathrm{T}$ helper (Th) differentiation toward Th1, while high doses of estrogen favors the Th2 phenotype [30]. Increased expression of PD-1 has also been shown to be mediated by estrogen [29]. Although the regulatory role of sex hormones in the immune system is well established, they have not been assessed during immunotherapy of mRCC.

In the present study, we have therefore monitored hormones of pituitary-gonadal axis in $22 \mathrm{mRCC}$ patients during anti-PD-1 immunotherapy with nivolumab, evaluating their relation to immunotherapy response and oncological prognosis. 


\section{Patients and methods}

\section{Study populations and data collection}

We performed a retrospective analysis of a prospectively collected database of 22 patients with mRCC undergoing immunotherapy with the PD-1 inhibitor nivolumab at our department between May 2016 and January 2020. The study was approved by a local institutional review board (ethics committee study number: 1202/2018). In April 2016, nivolumab was approved for intravenous (IV) administration of a $3 \mathrm{mg} / \mathrm{kg}$ dose once every 2 weeks in 12 -week treatment cycles. Modifications of the dosage regimen to a flat dose of $240 \mathrm{mg}$ as single dose every two weeks and $480 \mathrm{mg}$ every four weeks were approved in September 2016 and June 2018, respectively [31].

Data were collected from patients' electronic medical records including demographic information, smoking behavior, sequence of systemic therapy, duration of treatment, best response to PD-1 inhibition, date of progression, date of death or last follow-up at our outpatient department and detailed RCC histology. Quantitative serum measurements of LH, FSH, LH/FSH ratio, $\mathrm{E} 2$, testosterone and prolactin were performed enzymelinked immunosorbent assay (ELISA) at three different landmarks. The first measurement was at the beginning of nivolumab therapy (baseline/week 0). Due to a regimen change from $240 \mathrm{mg}$ every two weeks to $480 \mathrm{mg}$ every four weeks, the landmark analyses were performed at 6 and 8 weeks, respectively, (interim analysis/week 6/8). The final evaluation was carried out at week 12 (final analysis/week 12). Sex-specific reference values for men were 0.8-7.6 U/L for LH, 1.6-20.4 U/L for FSH, 11-43 ng/L for E2, 1.70-4.90 $\mu \mathrm{g} / \mathrm{L}$ for testosterone and $2.5-17.0 \mu \mathrm{g} / \mathrm{L}$ for prolactin. According to medical history, all female patients were confirmed to be postmenopausal without ongoing hormone replacement therapy. Female reference values were $11.3-39.8 \mathrm{U} / \mathrm{L}$ for $\mathrm{LH}, 35.0-150.0 \mathrm{U} / \mathrm{L}$ for $\mathrm{FSH},<13-65 \mathrm{ng} / \mathrm{L}$ for $\mathrm{E} 2,0.00-0.40 \mu \mathrm{g} / \mathrm{L}$ for testosterone and $1.9-25.0 \mu \mathrm{g} / \mathrm{L}$ for prolactin.

Furthermore, we performed an exact calculation according to IMDC risk model for $\mathrm{mRCC}$ on the basis of the following values: hemoglobin $<$ lower limit of laboratory reference range, corrected calcium $>10.0 \mathrm{mg} / \mathrm{dL}$ $(2.4 \mathrm{mmol} / \mathrm{L})$, platelets $>$ upper limit of normal, absolute neutrophil count $($ ANC) $>$ upper limit of normal, Karnofsky Performance Status (KPS) $<80 \%$, and time from diagnosis to systemic treatment $<1$ year before starting first-line therapy [32].

Response and progression were determined via computed tomography (CT) at week 12 using the Response Evaluation Criteria in Solid Tumor version 1.1 (RECIST
1.1) criteria [33] by two uro-radiologists (F.A. and F.S.). Stable disease (SD), partial remission (PR) or complete remission (CR) as primary response were necessary for treatment continuation. ORR was defined as the number of patients with complete response or partial response divided by the total number of patients. Best overall response was defined as the best response from therapy start to progression or subsequent therapy, whichever occurred first. PFS and OS were defined as time from therapy initiation to death from all causes for OS and to progression, treatment discontinuation or tumor-specific death for PFS, censored at last follow-up for those still alive or who have not progressed.

\section{Statistical analysis}

Statistical analyses were carried out using SPSS version 24 (IBM Corp. Chicago, IL, USA). Graphs and Figures were made using SPSS version 24 (IBM Corp. Chicago, IL, USA) and GraphPad Prism 8.4.1. Descriptive statistics for continuous variables are reported as means with standard deviation if the data showed normal distribution as well as medians and interquartile ranges (IQR), if the data failed the test for normality. Kolmogorov-Smirnov and Shapiro-Wilk tests were used to test the data for normal distribution. Categorical variables are reported as frequencies and percentages. Continuous variables between patient groups were compared by the Student's t-test in case of normal distributed data and the Mann-Whitney U test, in case of data that deviated from normal distribution. ANOVA and the paired t-test were used for repeated measurements to show changes in LH, FSH, LH/FSH ratio, E2, testosterone and prolactin between baseline and after 12 weeks of treatment, if the data passed the tests for normality. If data do not allow parametric testing Kruskal-Wallis and Friedman tests were applied. The associations between sex hormones and response to therapy were analyzed by an independent t-test, if normal distributed and the Mann-Whitney U test, if the normality could not be shown. All statistical tests were two-sided, and overall statistical significance was defined as $p<0.05$. Bonferroni method was applied to correct for multiple comparisons. Regarding survival and response, which were separately assessed in females and males, a $p<0.025$ was considered to indicate statistical significance. Regarding the repeated measurements with additional evaluation at two evaluation time points (interim/final evaluation) a $p<0.0125$ was chosen.

To examine the sex hormone status and its associations with survival, patients were split into a high and low group using the gender-specific median as cutoff level. Correlations between hormonal changes and OS or PFS were analyzed by applying Kaplan-Meier survival analysis, the cutoff was dichotomized in low vs. high at the median of 0.69 for 
the male population and at the median of 0.36 for the female population.

For the LH/FSH ratio, receiver operating characteristic (ROC) curves were plotted, and the area under the curve (AUC) was calculated. The optimal cutoff value for the LH/ FSH ratio at week 6/8 was determined as the value with the highest Youden index.

\section{Results}

\section{Baseline characteristics}

This study included 22 (10 women and 12 men) patients with mRCC who received treatment with nivolumab between May 2016 and January 2020. Baseline characteristics are presented in Table 1 . The female population was significantly older than the male patients (median age: 70.5 vs. $61.5 ; p=0.024)$. The majority $(\mathrm{n}=18 ; 81.8 \%)$ of patients had histology of clear cell RCC, three patients had papillary RCC and one individual a chromophobe RCC. According to IMDC criteria, three patients were classified as poor risk, eight counted toward the favorable and nine toward the intermediate risk prognostic group. Two patients could not be assigned to a prognostic group according IMDC criteria, because of lack of data values. Patients had received at least one, but no more than five, prior antiangiogenic cancer therapies. Sixteen patients received nivolumab in second line, two patients in third line, three in fourth line and one patient in fifth line setting (Fig. 1).

An overview of sex-specific response rates is shown in Table 2. The ORR was $22.7 \%(\mathrm{n}=5)$ for the total population, $30 \%(n=3)$ in female and $16.7 \%(n=2)$ in male patients. Two female patients achieved CR, one PR and three SD as best overall response. In males, four patients achieved PR and two remained with SD. No significant gender-specific differences were noticed regarding therapy response. Median duration of PFS and OS follow-up after therapy initiation were 7.5 (range: 1-34) and 20.5 (range: 3-43) months in females, as well as 6 (range: 2-40) and 20.5 (7-40) in males.

\section{Sex-specific hormone characteristics}

The hormone values for men and women at baseline, at landmark of $6 / 8$ weeks and 12 weeks are presented in Table 3. The median LH/FSH ratio at baseline for women and men was 0.33 (range: $0.06-1.57$ ) and 0.58 (0.28-1.03), 0.36 (range: 0.09-0.67) and 0.685 (range: $0.27-1.03$ ) at $6 / 8$ weeks, 0.4 (range: $0.18-0.76$ ) and 0.72 (range: $0.21-1.34$ ) at landmark of 12 weeks. The median E2 value for women and men at baseline was $13 \mathrm{ng} / \mathrm{mL}$ (range: $13-25 \mathrm{ng} / \mathrm{mL}$ ) and $21 \mathrm{ng} / \mathrm{mL}$ (range: $13-33 \mathrm{ng} / \mathrm{mL}$ ), $13 \mathrm{ng} / \mathrm{mL}$ (range: $13-25 \mathrm{ng} / \mathrm{mL}$ ) and 30.5 (range: 13-39) at
6/8 weeks, $13 \mathrm{ng} / \mathrm{mL}$ (range: $13-31$ ) and 29 (range: 15-42) at landmark of 12 weeks.

We did not detect any significant associations between hormone levels/hormone ratios and descriptive patient characteristics neither at baseline nor at $6 / 8$ or 12 weeks.

\section{Sex-specific changes of FSH, E2 levels and LH/FSH ratios during immunotherapy with nivolumab}

During the period of treatment begin (week 0) and week 12, a significant increase in E2 levels in male patients could be observed ( $p=0.006$ ) (Fig. 2). In contrast, no significant changes in E2 levels were observed in female patients. We could additionally detect a significant increase in the LH/FSH ratio from baseline to week 12 in male patients ( $p=0.013$; borderline after Bonferroni correction) but not in female patients (Fig. 2). Likewise, FSH levels showed a significant decrease from baseline to week 12 in males $(p=0.011)$ but not in female patients (Fig. 2). No significant changes of LH, testosterone and prolactin levels were observed in the female as well as in the male population (supplementary Fig. 1).

\section{Increased LH/FSH ratio at interim analysis was significantly associated with immunotherapy response and survival}

Finally, we analyzed potential sex-specific associations between sex hormone levels either assessed at baseline or at $6 / 8$ and 12 weeks with response to nivolumab (SD, PR, CR) or outcomes (PFS, OS). At interim analysis, the association between LH/FSH ratio and PFS was apparent in male but not in female patients (Fig. 3). Moreover, the LH/FSH ratio at $6 / 8$ weeks also correlated with response to therapy in male patients (Fig. 4). LH/FSH ratios did not correlate with OS, neither in male nor in female patients. Finally, no other endocrine parameters correlated with response, PFS or OS in women or men (supplementary Figs. 2-14).

A ROC analysis of LH/FSH ratio at interim analysis showed an AUC of 0.92 (95\% CI. 0.742-1.000; $p=0.016$ ) to predict progression for males. The best cutoff calculated by highest Youden Index was at 0.605 for men. Sensitivity, specificity, PPV and NPV were shown to be $100 \%, 83 \%$, $74 \%$ and $100 \%$, respectively. ROC analysis for the female population revealed no significant results (AUC $=0.54 ; 95 \%$ CI: 0.08-1.00; $p=0.831$ ) (Fig. 5).

\section{Discussion}

Sex differences in immune responses, including antitumor responses have been reported in the past $[34,35]$. In metaanalyses, immune checkpoint inhibitors as single agents 
Table 1 Baseline patient characteristics

\begin{tabular}{|c|c|c|c|}
\hline & Females & Males & $P$ value \\
\hline \multicolumn{4}{|l|}{ Patients No. (\%) } \\
\hline Age at therapy start with nivolumab & 10 & 12 & \\
\hline Findings/missing & $10 / 0$ & $12 / 0$ & 0.024 \\
\hline Mean $\pm \mathrm{SD} /$ median $(\mathrm{IQR})$ & $70.60 \pm 9.06 / 70.5(54-85)$ & $60.42 \pm 10.66 / 61.50(43-76)$ & \\
\hline \multicolumn{4}{|l|}{ PFS nivolumab in months } \\
\hline Findings/missing & $10 / 0$ & $12 / 0$ & 0.889 \\
\hline Mean $\pm \mathrm{SD} /$ median $(\mathrm{IQR})$ & $11.7 \pm 11.31 / 7.5(1-34)$ & $11.00 \pm 11.85 / 6(2-40)$ & \\
\hline \multicolumn{4}{|l|}{ OS nivolumab in months } \\
\hline Findings/missing & $10 / 0$ & $12 / 0$ & 0.813 \\
\hline Mean $\pm \mathrm{SD} /$ median $(\mathrm{IQR})$ & $22.2 \pm 12.65 / 20.5(3-43)$ & $23.42 \pm 11.13 / 20.5(7-40)$ & \\
\hline \multicolumn{4}{|l|}{ Follow-up in months } \\
\hline Findings/missing & $10 / 0$ & $12 / 0$ & 0.171 \\
\hline Mean $\pm \mathrm{SD} /$ median $(\mathrm{IQR})$ & $36.9 \pm 18.99 / 29(19-76)$ & $51.58 \pm 27.67 / 46(14-98)$ & \\
\hline \multicolumn{4}{|l|}{ Smoking status } \\
\hline Findings/missing & $10 / 1$ & $11 / 1$ & 0.158 \\
\hline yes $(\%) /$ no $(\%)$ & $2(20) / 7(70)$ & $6(50) / 5(41.7)$ & \\
\hline \multicolumn{4}{|l|}{ ECOG at therapy start with nivolumab } \\
\hline Findings/missing & $10 / 0$ & $12 / 0$ & 0.157 \\
\hline No. ECOG $0(\%)$ & $4(40)$ & $8(66.7)$ & \\
\hline No. ECOG $1(\%)$ & $5(50)$ & $4(33.3)$ & \\
\hline No. ECOG $2(\%)$ & $1(10)$ & - & \\
\hline \multicolumn{4}{|l|}{ First-line therapy } \\
\hline Findings/missing & $9 / 0$ & $12 / 0$ & 0.703 \\
\hline No. Sunitinib (\%) & $6(60)$ & $5(41.7)$ & \\
\hline No. Pazopanib (\%) & $3(30)$ & $7(58.3)$ & \\
\hline No. Bevacizumab (\%) & $1(10)$ & - & \\
\hline \multicolumn{4}{|l|}{ Therapy-line nivolumab } \\
\hline Findings/missing & $10 / 0$ & $12 / 0$ & 0.361 \\
\hline No. Therapy in 2L (\%) & $8(80)$ & $8(66.7)$ & \\
\hline No. Therapy in 3L (\%) & $1(10)$ & $1(8.3)$ & \\
\hline No. Therapy in 4L (\%) & $1(10)$ & $2(16.7)$ & \\
\hline No. Therapy in 5L (\%) & - & $1(8.3)$ & \\
\hline \multicolumn{4}{|l|}{ Grade } \\
\hline Findings/missing & $9 / 1$ & 12 & 0.830 \\
\hline G1 $(\%)$ & $4(40)$ & $1(8.3)$ & \\
\hline $\mathrm{G} 2(\%)$ & $4(40)$ & $4(33.3)$ & \\
\hline G3 $(\%)$ & $1(10)$ & $4(33.3)$ & \\
\hline $\mathrm{G} 4(\%)$ & - & $3(25.0)$ & \\
\hline \multicolumn{4}{|l|}{ Histology } \\
\hline Findings/missing & $10 / 0$ & $12 / 0$ & 0.064 \\
\hline Clear cell renal carcinoma (\%) & $10(100)$ & $8(66.7)$ & \\
\hline Papillary renal cell carcinoma (\%) & - & $3(25)$ & \\
\hline Chromophobe renal cell carcinoma (\%) & - & $1(8.3)$ & \\
\hline \multicolumn{4}{|l|}{ Metastasis at therapy start with nivolumab } \\
\hline Findings/missing & $10 / 0$ & $12 / 0$ & 0.976 \\
\hline 1 metastasis $(\%)$ & $1(10)$ & $3(25)$ & \\
\hline 2 metastasis (\%) & $3(30)$ & $1(8.3)$ & \\
\hline$>4$ metastasis $(\%)$ & $6(60)$ & $8(66.7)$ & \\
\hline \multicolumn{4}{|l|}{ IMDC-Score } \\
\hline Findings/missing & $9 / 1$ & $11 / 1$ & 0.679 \\
\hline
\end{tabular}


Table 1 (continued)

\begin{tabular}{lll}
\hline & Females & Males \\
\hline 1 & $3(30)$ & $6(50)$ \\
2 & $5(50)$ & $3(25)$ \\
3 & $1(10)$ & $2(16.7)$ \\
\hline
\end{tabular}

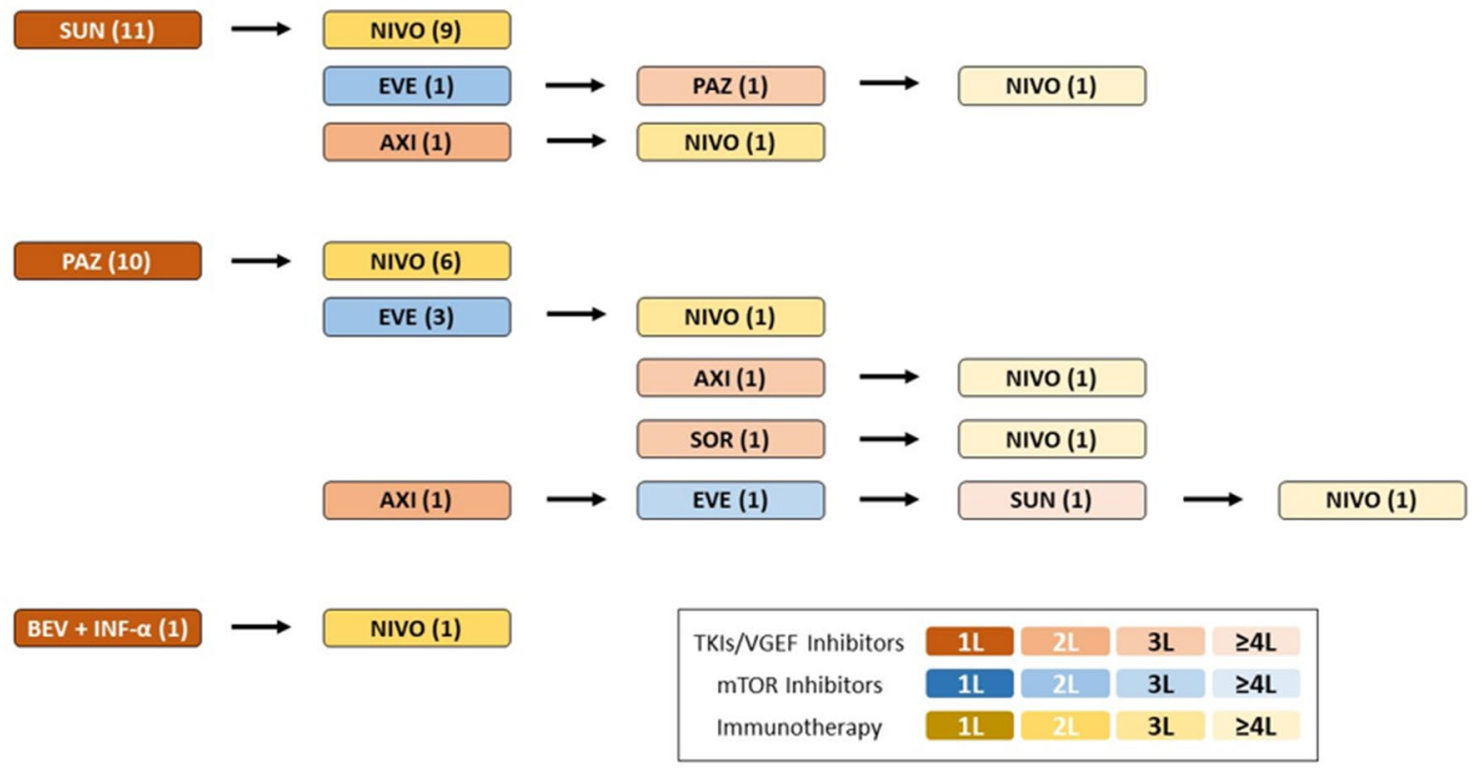

Fig. 1 Sequences of systemic therapy in the total population $(n=22)$. SUN sunitinib, PAZ pazopanib, BEV + INF- $\alpha=$ bevacizumab plus interferon alfa, NIVO nivolumab, EVE everolimus, AXI axitinib, SOR sorafenib

Table 2 Sex-specific response rates

\begin{tabular}{llll}
\hline & \multicolumn{1}{c}{ Females } & Males & $P$ value \\
\hline Patients No & 10 & 12 & \\
Therapy response after 12 weeks & & \\
CR, n (\%) & - & - & 0.516 \\
PR, n (\%) & $3(30)$ & $2(16.7)$ & \\
SD, n (\%) & $3(30)$ & $4(33.3)$ & \\
PD, n (\%) & $4(40)$ & $6(50)$ & \\
ORR, n (\%) & $3(30)$ & $2(16.7)$ & 0.481 \\
Best overall response, n (\%) & & \\
CR, n (\%) & $2(20)$ & - & \\
PR, n (\%) & $1(10)$ & $4(33.3)$ & \\
SD, n (\%) & $3(30)$ & $2(16.7)$ & \\
PD, n (\%) & $4(40)$ & $6(50)$ & \\
\hline
\end{tabular}

appear to be more effective in male cancer patients compared with female patients [23, 24, 36]. This controversially discussed data do not necessarily apply to RCC [37]. Potential effects of checkpoint inhibition on sex hormones have not yet been fully explored, leaving it more difficult to interpret current data.

In present work, we report on changes in sex hormones in mRCC patients undergoing nivolumab therapy. We observed a significant increase in E2 levels in male but not in female patients between treatment start and the last follow-up at week 12 . In addition, we could detect a significant increase in the LH/FSH ratio from baseline to week 12 in male patients but not in female patients. Our findings indicate that the increase in the LH/FSH ratio is most likely due to a decrease in FSH levels. At interim analysis at 6/8 weeks, an association between LH/FSH ratio and PFS was apparent in male but not in female patients. Moreover, the LH/FSH ratio at $6 / 8$ weeks also correlated with response to therapy in male patients, yet LH/FSH ratios did not correlate with $\mathrm{OS}$, neither in male nor in female patients.

The nivolumab-induced increase in E2 levels in male patients is of interest, because in vitro data as well as preclinical and clinical evidence suggest a role for E2 in the upregulation of PD-1 and PD-L1 expression [29, 38, 39]. The PD-L1 pathway has also been implicated in feto-maternal tolerance during pregnancy both in animal models [40] 
Table 3 Sex-specific hormone characteristics

\begin{tabular}{|c|c|c|}
\hline & Females & Males \\
\hline Patients No & 10 & 12 \\
\hline \multicolumn{3}{|l|}{$\mathrm{LH}$-week 0 in $\mathrm{U} / \mathrm{L}$} \\
\hline Findings/missing & $9 / 1$ & $12 / 0$ \\
\hline Mean $\pm \mathrm{SD} /$ median $(\mathrm{IQR})$ & $29.23 \pm 23.71 / 23.0(0.4-60.5)$ & $7.08 \pm 3.32 / 6.15(3.8-14.9)$ \\
\hline \multicolumn{3}{|l|}{$\mathrm{LH}$-week $6 / 8$ in $\mathrm{U} / \mathrm{L}$} \\
\hline Findings/missing & $10 / 0$ & $12 / 0$ \\
\hline Mean $\pm \mathrm{SD} /$ median $(\mathrm{IQR})$ & $27.95 \pm 23.41 / 21.4(0.3-65.0)$ & $6.57 \pm 3.47 / 5.75(3.3-16)$ \\
\hline \multicolumn{3}{|l|}{$\mathrm{LH}$-week 12 in U/L } \\
\hline Findings/missing & $10 / 0$ & $12 / 0$ \\
\hline Mean $\pm \mathrm{SD} /$ median $(\mathrm{IQR})$ & $32.13 \pm 21.10 / 24.4(13.1-76.7)$ & $7.55 \pm 5.7 / 5.2(4.0-21.3)$ \\
\hline \multicolumn{3}{|l|}{$\mathrm{FSH}$-week 0 in $\mathrm{U} / \mathrm{L}$} \\
\hline Findings/missing & $9 / 1$ & $11 / 1$ \\
\hline Mean $\pm \mathrm{SD} /$ median $(\mathrm{IQR})$ & $75.90 \pm 50.12 / 69.4(4.8-170.0)$ & $13.92 \pm 6.97 / 10.9(6.4-29.3)$ \\
\hline \multicolumn{3}{|l|}{ FSH-week $6 / 8$ in U/L } \\
\hline Findings/missing & $10 / 0$ & $12 / 0$ \\
\hline Mean $\pm \mathrm{SD} /$ median $(\mathrm{IQR})$ & $67.38 \pm 45.63 / 56.6(3.3-170.0)$ & $11.07 \pm 6.12 / 9.3(4.2-25.4)$ \\
\hline \multicolumn{3}{|l|}{ FSH-week 12 in U/L } \\
\hline Findings/missing & $10 / 0$ & $12 / 0$ \\
\hline Mean $\pm \mathrm{SD} /$ median $(\mathrm{IQR})$ & $73.59 \pm 35.62 / 67.95(21.0-151.0)$ & $10.93 \pm 6.24 / 8.7(4.1-24.8)$ \\
\hline \multicolumn{3}{|l|}{ LH/FSH ratio-week 0} \\
\hline Findings/missing & $9 / 1$ & $11 / 1$ \\
\hline Mean $\pm \mathrm{SD} /$ median $(\mathrm{IQR})$ & $0.32 \pm 0.17 / 0.33(0.06-0.57)$ & $0.58 \pm 0.24 / 0.58(0.28-0.89)$ \\
\hline \multicolumn{3}{|l|}{$\mathrm{LH} / \mathrm{FSH}$ ratio-week $6 / 8$} \\
\hline Findings/missing & $10 / 0$ & $12 / 0$ \\
\hline Mean $\pm \mathrm{SD} /$ median $(\mathrm{IQR})$ & $0.36 \pm 0.18 / 0.36(0.09-0.67)$ & $0.68 \pm 0.28 / 0.69(0.27-1.03)$ \\
\hline \multicolumn{3}{|l|}{ LH/FSH ratio-week 12} \\
\hline Findings/missing & $10 / 0$ & $12 / 0$ \\
\hline Mean $\pm \mathrm{SD} /$ median $(\mathrm{IQR})$ & $0.44 \pm 0.16 / 0.4(0.18-0.76)$ & $0.77 \pm 0.34 / 0.72(0.21-1.34)$ \\
\hline \multicolumn{3}{|l|}{$\mathrm{E} 2$-week 0 in $\mathrm{ng} / \mathrm{mL}$} \\
\hline Findings/missing & $9 / 1$ & $12 / 0$ \\
\hline Mean $\pm \mathrm{SD} /$ median $(\mathrm{IQR})$ & $17.00 \pm 5.10 / 13.0(13-25)$ & $22.25 \pm 7.20 / 21.00(13-33)$ \\
\hline \multicolumn{3}{|l|}{$\mathrm{E} 2$ - week $6 / 8 \mathrm{in} \mathrm{ng} / \mathrm{mL}$} \\
\hline Findings/missing & $10 / 0$ & $12 / 0$ \\
\hline Mean $\pm \mathrm{SD} /$ median $(\mathrm{IQR})$ & $14.80 \pm 4.05 / 13.00(13-25)$ & $29.00 \pm 6.84 / 30.50(13-39)$ \\
\hline \multicolumn{3}{|l|}{ E2-week 12 in $\mathrm{ng} / \mathrm{mL}$} \\
\hline Findings/missing & $10 / 0$ & $12 / 0$ \\
\hline Mean $\pm \mathrm{SD} /$ median $(\mathrm{IQR})$ & $16.60 \pm 6.45 / 13.00(13-31)$ & $28.58 \pm 7.01 / 29(15-42)$ \\
\hline \multicolumn{3}{|c|}{ Testosterone-week 0 in $\mu \mathrm{g} / \mathrm{mL}$} \\
\hline Findings/missing & $9 / 1$ & $12 / 0$ \\
\hline Mean $\pm \mathrm{SD} /$ median $(\mathrm{IQR})$ & $0.17 \pm 0.08 / 0.14(0.10-0.33)$ & $3.73 \pm 1.58 / 3.56(1.48-7.61)$ \\
\hline \multicolumn{3}{|c|}{ Testosterone-week $6 / 8$ in $\mu \mathrm{g} / \mathrm{mL}$} \\
\hline Findings/missing & $10 / 0$ & $12 / 0$ \\
\hline Mean $\pm \mathrm{SD} /$ median $(\mathrm{IQR})$ & $0.15 \pm 0.5 / 0.14(0.10-0.24)$ & $3.90 \pm 1.18 / 4.08(2.47-6.05)$ \\
\hline \multicolumn{3}{|c|}{ Testosterone—week 12 in $\mu \mathrm{g} / \mathrm{mL}$} \\
\hline Findings/missing & $10 / 0$ & $12 / 0$ \\
\hline Mean $\pm \mathrm{SD} /$ median $(\mathrm{IQR})$ & $0.15 \pm 0.06 / 0.13(0.10-0.25)$ & $3.63 \pm 1.18 / 3.58(1.73-6.09)$ \\
\hline \multicolumn{3}{|l|}{ Prolactin—week 0 in $\mu \mathrm{g} / \mathrm{mL}$} \\
\hline Findings/missing & $10 / 0$ & $10 / 2$ \\
\hline Mean $\pm \mathrm{SD} /$ median $(\mathrm{IQR})$ & $14.20 \pm 18.12 / 9.5(6.00-65.90)$ & $11.38 \pm 9.72 / 8.40(2.20-35.30)$ \\
\hline \multicolumn{3}{|c|}{ Prolactin—week $6 / 8$ in $\mu \mathrm{g} / \mathrm{mL}$} \\
\hline Findings/missing & $10 / 0$ & $12 / 0$ \\
\hline
\end{tabular}


Table 3 (continued)

\begin{tabular}{|c|c|c|}
\hline & Females & Males \\
\hline Mean $\pm \mathrm{SD} /$ median $(\mathrm{IQR})$ & $16.69 \pm 22.30 / 9.95(5.10-79.30)$ & $11.85 \pm 7.64 / 10.05(3.50-30.60)$ \\
\hline \multicolumn{3}{|c|}{ Prolactin—week 12 in $\mu \mathrm{g} / \mathrm{mL}$} \\
\hline Findings/missing & $10 / 0$ & $12 / 0$ \\
\hline Mean $\pm \mathrm{SD} /$ median $(\mathrm{IQR})$ & $13.25 \pm 12.00 / 9.70(6.80-45.30)$ & $10.78 \pm 7.15 / 8.70(2.40-25.80)$ \\
\hline
\end{tabular}

Females

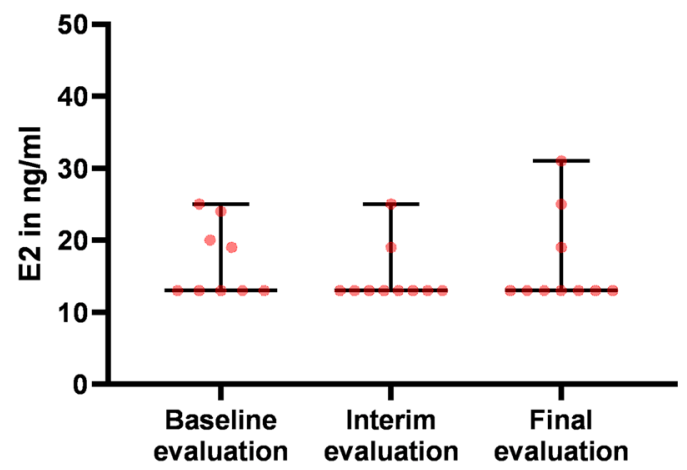

Females

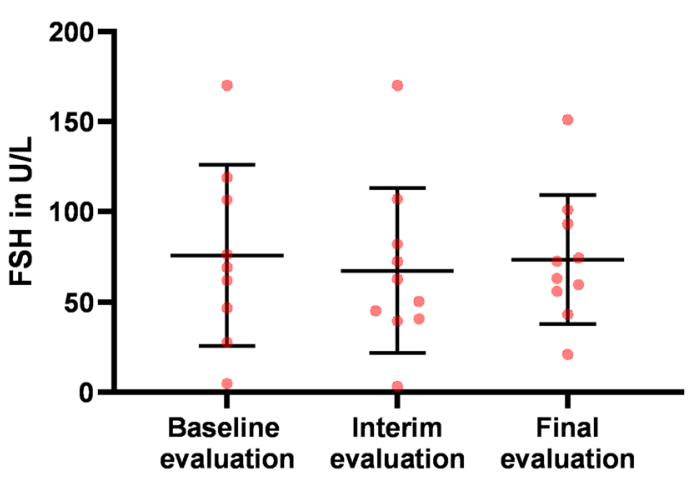

Females

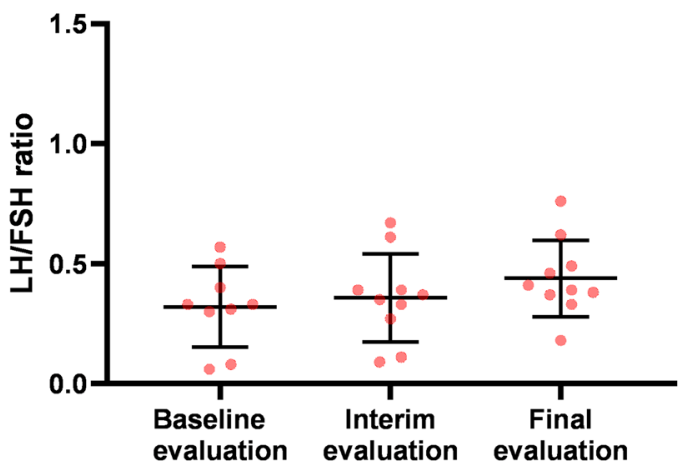

Fig. 2 Dynamic changes of a 17-ß-estradiol (E2); b FSH and c LH/ FSH ratio during nivolumab therapy stratified by sex. Evaluations were performed at week 0 (baseline evaluation), 6/8 week (interim evaluation) and week 12 (final evaluation). Changes are tested for significance between treatment begin (week 0) and week 12. The
Males

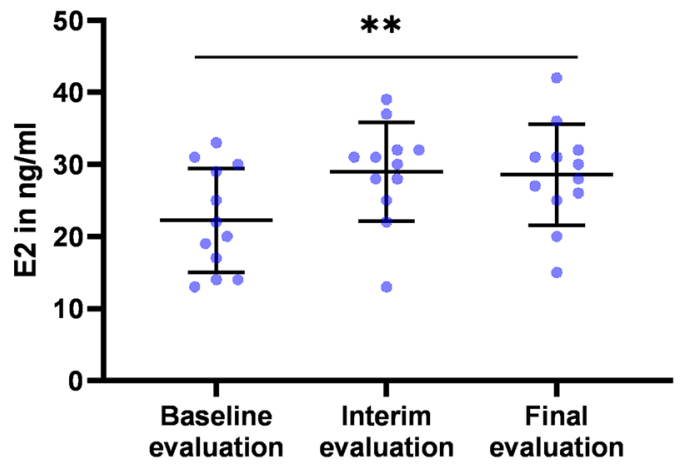

\section{Males}

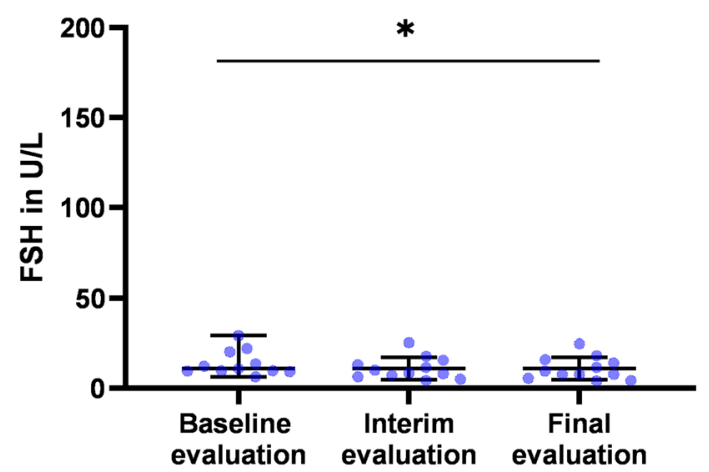

Males

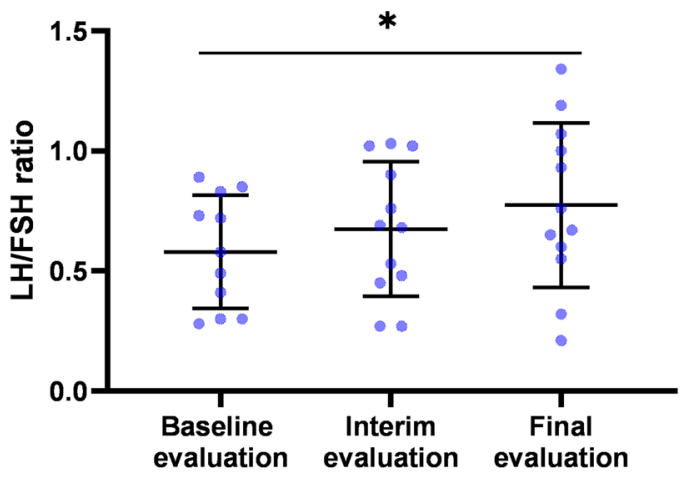

bar graph is showing mean $\pm \mathrm{SD}$ for all hormone parameters with the exception of E2 in females. Here, the data are not normally distributed, so median and range were used. * $p<0.05$; ** $p<0.01$; *** $p<0.001$ 

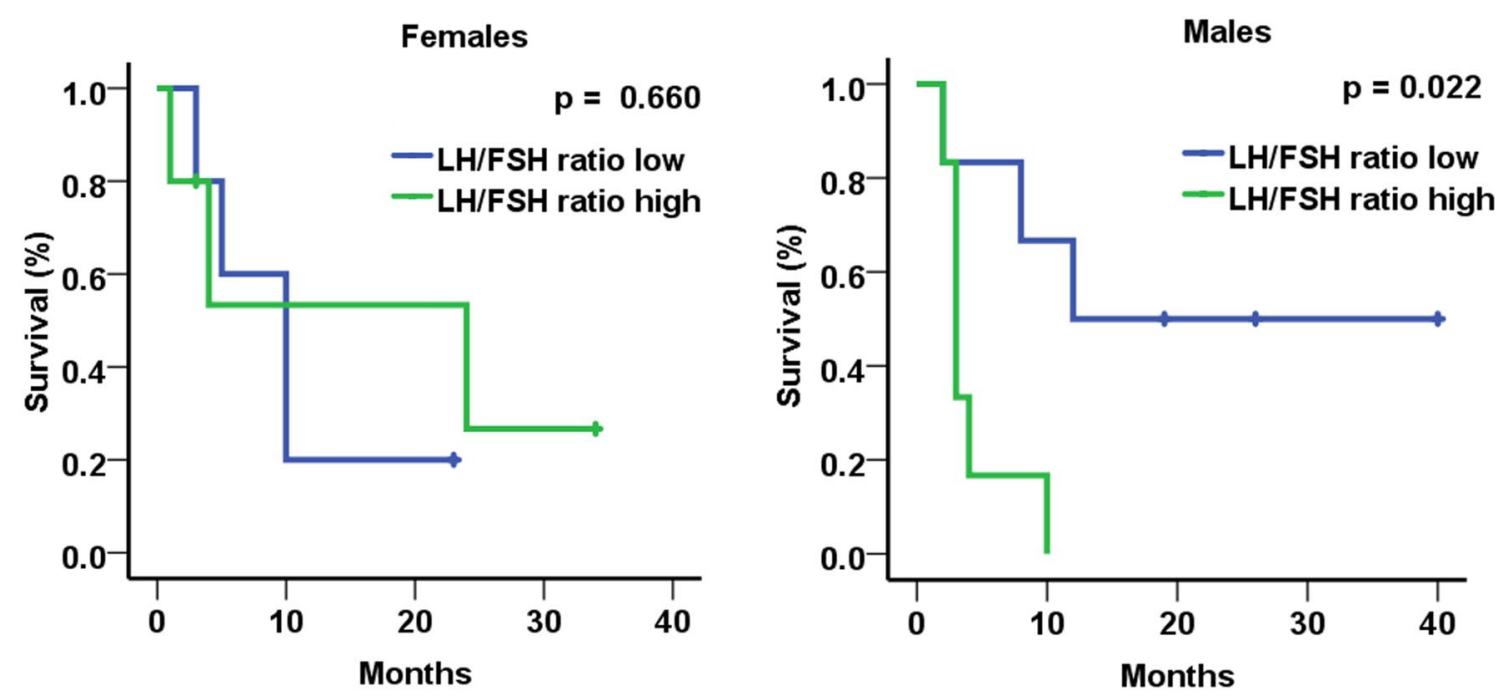

Fig. 3 PFS according to LH/FSH ratio at 6/8 weeks landmark (low vs. high, dichotomized at the median of 0.69 for male population and at the median of 0.36 for female population. The bar graph is showing mean $\pm \mathrm{SD}$

\section{Females}

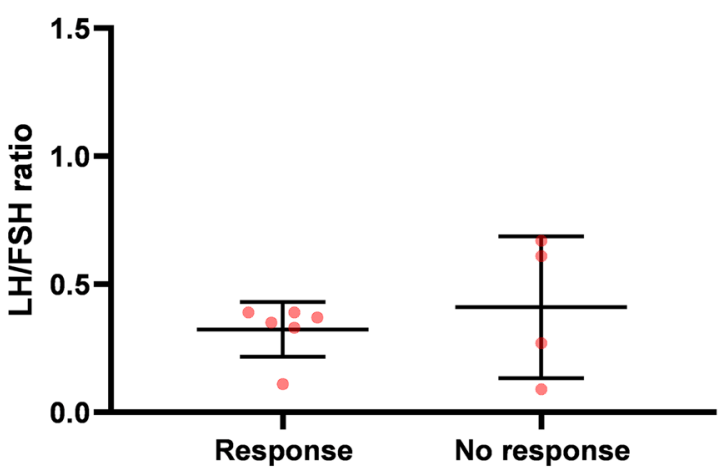

Fig. 4 LH/FSH ratio at landmark of $6 / 8$ weeks is associated with therapy response for the male but not for the female population. Therapy response was defined as SD, PR, CR by RECIST in monitor-

and in humans [29]. Female hormones such as E2 are supposed to maintain feto-maternal tolerance by enhancing PD-1 expression in several types of antigen-presenting cells and in regulatory $\mathrm{T}$ cells [29], thus preventing an immunemediated fetal rejection. Similarly, E2-driven tumor tolerance may limit the efficacy of nivolumab-based immunotherapy. In addition to positive and negative E2 effects on immune cells $[25,26,30]$, E2 has also been shown to directly promote RCC growth in a mouse model [41]. Moreover, women with five or more births had a two-fold increase in $\mathrm{mRCC}$ risk when compared to those with one or two births [42]. In animal melanoma models, PD-1 inhibition using nivolumab has been shown to increase IL-6 production by macrophages in the tumor microenvironment. In melanoma patients, increased systemic levels of IL-6

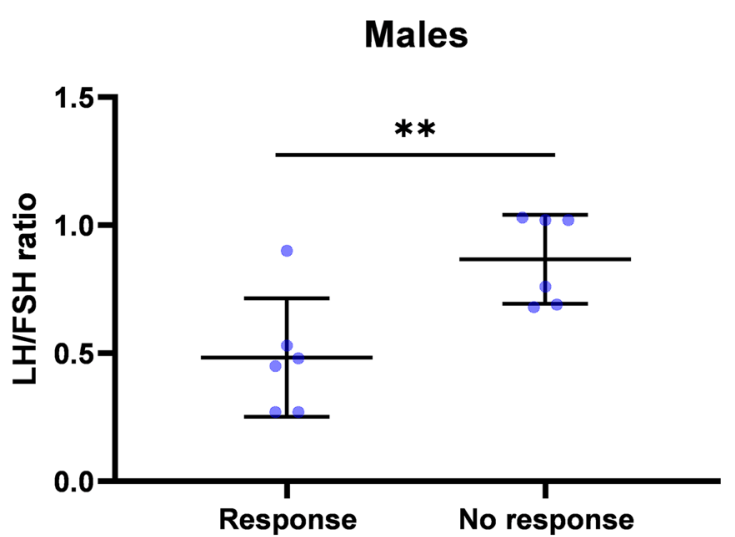

ing CT after 12 weeks of treatment with nivolumab. The bar graph is showing mean \pm SD. $* p<0.05 ; * * p<0.01 ; * * * p<0.001$

were associated with poor clinical response [43]. IL-6 can stimulate E2 synthesis [44], then again E2 further upregulates PD-1 and PD-L1 expression [29, 38, 39], generating a feedforward immunosuppressive mechanism. In estrogen receptor $\alpha(\mathrm{ER} \alpha)$, positive endometrial and breast cancer cell lines E2 can increase PD-L1 protein expression via the phosphoinositide 3 kinase (PI3K)/Akt pathway and posttranscriptional PD-L1 mRNA stabilization [45].

Extragonadal E2 production has been shown in non-small cell lung cancer (NSCLC). E2 concentration in NSCLC tissue was 2.2 fold higher than basal levels in non-neoplastic lung tissues [46]. Increased E2 levels were positively correlated with aromatase expression in tumor tissues, suggesting local E2 production [46]. High aromatase expression has also been demonstrated to be a poor predictor of survival 

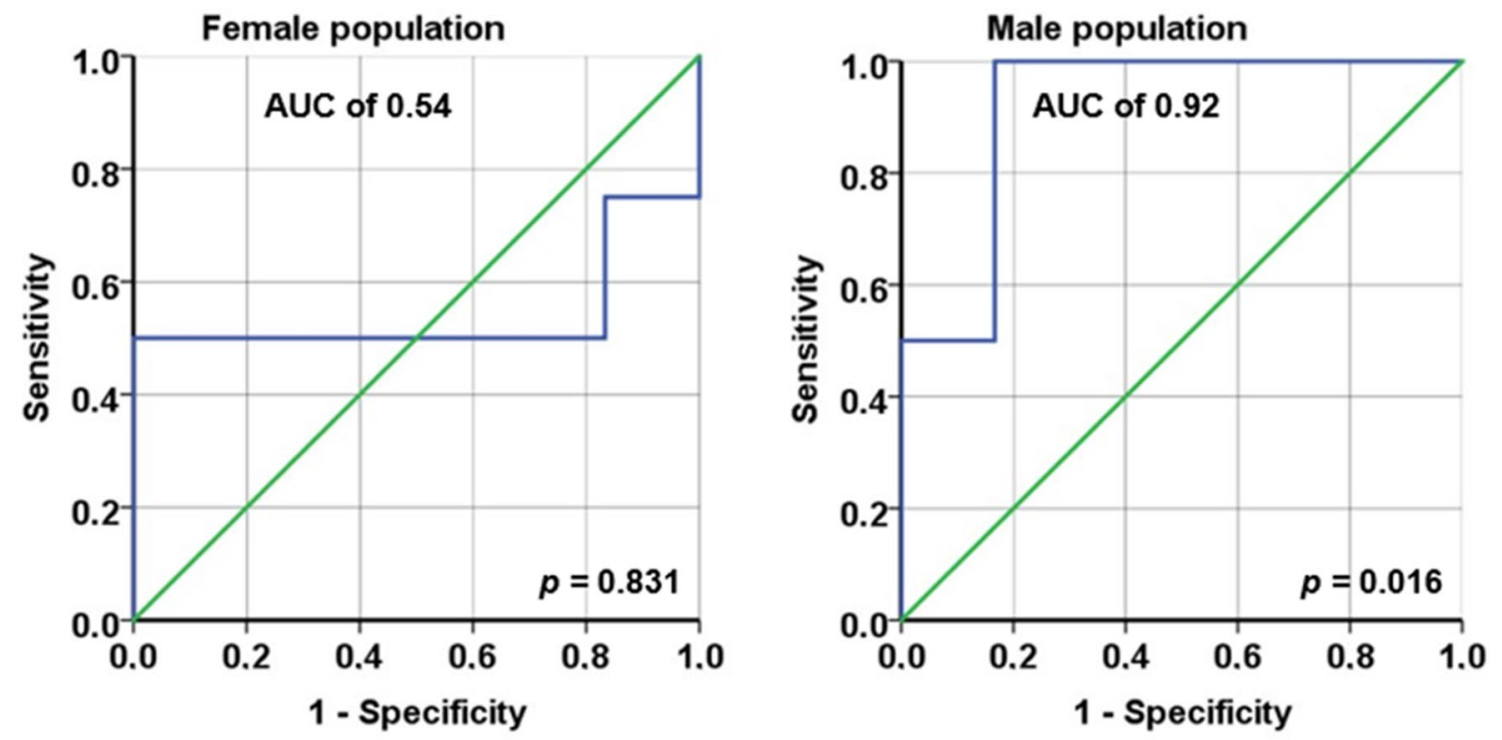

Fig. 5 Sex-specific ROC curves for LH/FSH ratio (at 6/8 weeks) to predict progression

in both sexes in early stage NSCLC patients, especially in women $\geq 65$ years [47]. Additionally, the combination of ER $\beta$ and aromatase expression in NSCLC was a stronger predictor of poor survival than ER $\beta$ alone in women and men [47].

In our male patients, we observed an increase in E2 during nivolumab therapy. In contrast, testosterone remained unaffected. This suggests extragonadal E2 synthesis in RCC patients similar to NSCLC patients [47]. LH and FSH are members of the gonadotropin family of pituitary hormones that are secreted by the anterior pituitary gland. FSH can stimulate gonadal E2 production and conversely increasing E2 levels can result in a negative feedback on pituitary to attenuate FSH secretion $[48,49]$. In line with this, a reduction in FSH during immunotherapy could be detected in our male patients. However, we did not find any association between E2 levels and therapy response, which would indicate its immunosuppressive effects. Instead, LH/FSH ratios were negatively associated with therapy response and PFS in males at interim analysis. Why the observed effect was undetectable at the last follow-up is currently unclear. Notably, the role of LH/FSH ratio has not yet been investigated in RCC. Increased E2 production may in fact result from nivolumab-mediated PD-1 blockade, representing an attempt to enhance E2-driven PD-1 expression in order to maintain immunological tolerance. Concomitantly, E2-mediated attenuation of FSH secretion through negative feedback on pituitary may cause the increase in LH/FSH ratios. The correlation of high LH/FSH ratio with poor PFS and therapy failure at interim analysis may thus reflect pro-tumor effects of nivolumab-induced E2 regulation. On the other hand, during prolonged treatment, E2-driven PD-1 expression would permanently offer additional nivolumab targets, a beneficial E2 effect that may eliminate the correlation between LH/ FSH ratio and PFS/therapy failure at the final analysis.

Beneficial effects of $\mathrm{E} 2$ have also been described. A population-based study recently reported that female sex was a significant predictor of poor renal cancer-specific mortality for advanced disease, however, only in postmenopausal period [50]. In addition, E2 has also been shown to inhibit RCC growth in vitro via an estrogen receptor- $\beta$ (ERB) dependent pathway [51]. Finally, hormonal agents such as medroxyprogesterone were initially shown to be active in metastatic RCC, although the response rates reported in various studies were modest, ranging from 7 to $25 \%[52,53]$. RCC incidence seems to increase in females after hysterectomy, suggesting that a decrease in E2 after hysterectomy may be one of the causes of this increased risk [54]. However, our female patients demonstrated neither E2 upregulation nor feedback inhibition of FSH secretion in response to nivolumab. All of them were postmenopausal, none of them receiving any type of hormone replacement therapy. Since RCC usually occurs between the $6^{\text {th }}$ and $7^{\text {th }}$ decade of life, age becomes a surrogate for hormone status and female RCC patients will most commonly be postmenopausal.

Our study has certain limitations. The most restrictive fact is our small population number and the short follow-up after therapy start. Especially for OS (median follow-up of only 23.8 months), a follow-up completeness is essential for reliable outcome assessments [55]. In such a small population, the heterogeneous group with women still being underrepresented compared with men, could have a significant influence on study results with limited statistical power, as ROC analysis cannot be considered very reliable. Moreover, 
we could include only postmenopausal patients. Further, our patient collective received diverse pre-treatments. Only sixteen patients were treated with nivolumab in second line and the possible effect on sex hormone changes by the previous multiple treatment modalities in other six patients remains unclear. Thus, our results are only hypothesis-generating and no definitive conclusions can be drawn yet.

In summary, we present first data on sex hormone modulation during immune checkpoint inhibition in patients with mRCC. An increase in E2, LH/FSH ratio and a decrease in FSH in males but not in females could be observed. LH/FSH ratio at interim analysis correlated with PFS and response rates. Our findings suggest further investigation of sex hormones and its association with efficacy of cancer immunotherapy to elucidate the complete mechanisms of such findings. Monitoring of sex hormones to evaluate these parameters as possible prognostic markers and the analysis of the interaction between sex hormone signaling and antitumor immunity during immune checkpoint inhibition should be the focus of larger clinical trials.

Supplementary Information The online version contains supplementary material available at (https://doi.org/10.1007/s00262-021-02882 $-\mathrm{y})$

Author contributions G.T. and M.T. conceived the research. G.T. performed the patient record reviews. H.U. was responsible for statistical analysis. G.T., N.S., A.K.L., R.P. and M.T. analyzed and interpreted the data. G.T., R.P. and M.T. drafted the manuscript. F.S. and F.A. contributed radiological images and RECIST evaluation. A.B. and B.Z. performed the pathological examination. W.H., R.P. and M.T. were responsible for supervision. All authors made substantial contributions to the manuscript draft and critically revised it. All authors have read and agreed to the final version of the manuscript.

Funding Open access funding provided by University of Innsbruck and Medical University of Innsbruck.. This work was supported by a personal research grant to G.T. by the Medical Research Foundation Tyrol (MFF Tirol, project number 297).

\section{Compliance with ethical standards}

Conflicts of interest The authors declare that there is no conflict of interest regarding the publication of this paper.

Open Access This article is licensed under a Creative Commons Attribution 4.0 International License, which permits use, sharing, adaptation, distribution and reproduction in any medium or format, as long as you give appropriate credit to the original author(s) and the source, provide a link to the Creative Commons licence, and indicate if changes were made. The images or other third party material in this article are included in the article's Creative Commons licence, unless indicated otherwise in a credit line to the material. If material is not included in the article's Creative Commons licence and your intended use is not permitted by statutory regulation or exceeds the permitted use, you will need to obtain permission directly from the copyright holder. To view a copy of this licence, visit http://creativecommons.org/licenses/by/4.0/.

\section{References}

1. Van Poppel H, Joniau S, Van Gool SW (2009) Vaccine therapy in patients with renal cell carcinoma. Eur Urol 55(6):1333-1342. https://doi.org/10.1016/j.eururo.2009.01.043

2. Motzer RJ, Bacik J, Murphy BA, Russo P, Mazumdar M (2002) Interferon-alfa as a comparative treatment for clinical trials of new therapies against advanced renal cell carcinoma. J Clin Oncol 20(1):289-296. https://doi.org/10.1200/JCO.2002.20.1.289

3. Negrier S, Perol D, Ravaud A, Chevreau C, Bay JO, Delva R, Sevin E, Caty A, Escudier B, French Immunotherapy I (2007) Medroxyprogesterone, interferon alfa-2a, interleukin 2, or combination of both cytokines in patients with metastatic renal carcinoma of intermediate prognosis: results of a randomized controlled trial. Cancer 110(11):2468-2477. https://doi. org/10.1002/cncr.23056

4. Rosenberg SA, Lotze MT, Yang JC, Topalian SL, Chang AE, Schwartzentruber DJ, Aebersold P, Leitman S, Linehan WM, Seipp CA et al (1993) Prospective randomized trial of high-dose interleukin-2 alone or in conjunction with lymphokine-activated killer cells for the treatment of patients with advanced cancer. J Natl Cancer Inst 85(8):622-632. https://doi.org/10.1093/ jnci/85.8.622

5. Yang JC, Sherry RM, Steinberg SM, Topalian SL, Schwartzentruber DJ, Hwu P, Seipp CA, Rogers-Freezer L, Morton KE, White DE, Liewehr DJ, Merino MJ, Rosenberg SA (2003) Randomized study of high-dose and low-dose interleukin-2 in patients with metastatic renal cancer. J Clin Oncol 21(16):31273132. https://doi.org/10.1200/JCO.2003.02.122

6. Simons JW, Jaffee EM, Weber CE, Levitsky HI, Nelson WG, Carducci MA, Lazenby AJ, Cohen LK, Finn CC, Clift SM, Hauda KM, Beck LA, Leiferman KM, Owens AH Jr, Piantadosi S, Dranoff G, Mulligan RC, Pardoll DM, Marshall FF (1997) Bioactivity of autologous irradiated renal cell carcinoma vaccines generated by ex vivo granulocyte-macrophage colonystimulating factor gene transfer. Cancer Res 57(8):1537-1546

7. Holtl L, Rieser C, Papesh C, Ramoner R, Bartsch G, Thurnher M (1998) CD83+ blood dendritic cells as a vaccine for immunotherapy of metastatic renal-cell cancer. Lancet 352(9137):1358. https://doi.org/10.1016/s0140-6736(05)60748-9

8. Leonhartsberger N, Ramoner R, Putz T, Gander H, Rahm A, Falkensammer C, Bartsch G, Thurnher M (2007) Antigenindependent immune responses after dendritic cell vaccination. Cancer Immunol Immunother 56(6):897-903. https://doi. org/10.1007/s00262-006-0245-4

9. Leonhartsberger N, Ramoner R, Falkensammer C, Rahm A, Gander H, Holtl L, Thurnher M (2012) Quality of life during dendritic cell vaccination against metastatic renal cell carcinoma. Cancer Immunol Immunother 61(9):1407-1413. https:// doi.org/10.1007/s00262-012-1207-7

10. McDermott DF, Drake CG, Sznol M, Choueiri TK, Powderly JD, Smith DC, Brahmer JR, Carvajal RD, Hammers HJ, Puzanov I, Hodi FS, Kluger HM, Topalian SL, Pardoll DM, Wigginton JM, Kollia GD, Gupta A, McDonald D, Sankar V, Sosman JA, Atkins MB (2015) Survival, Durable Response, and Long-Term Safety in Patients With Previously Treated Advanced Renal Cell Carcinoma Receiving Nivolumab. J Clin Oncol 33(18):20132020. https://doi.org/10.1200/JCO.2014.58.1041

11. Motzer RJ, Escudier B, McDermott DF, George S, Hammers HJ, Srinivas S, Tykodi SS, Sosman JA, Procopio G, Plimack ER, Castellano D, Choueiri TK, Gurney H, Donskov F, Bono P, Wagstaff J, Gauler TC, Ueda T, Tomita Y, Schutz FA, Kollmannsberger C, Larkin J, Ravaud A, Simon JS, Xu LA, Waxman IM, Sharma P, CheckMate I (2015) Nivolumab versus 
Everolimus in Advanced Renal-Cell Carcinoma. N Engl J Med 373(19):1803-1813. https://doi.org/10.1056/NEJMoa1510665

12. Cella D, Grunwald V, Nathan P, Doan J, Dastani H, Taylor F, Bennett B, DeRosa M, Berry S, Broglio K, Berghorn E, Motzer RJ (2016) Quality of life in patients with advanced renal cell carcinoma given nivolumab versus everolimus in CheckMate 025: a randomised, open-label, phase 3 trial. Lancet Oncol 17(7):994-1003. https://doi.org/10.1016/S1470-2045(16)30125 $-5$

13. Escudier B, Sharma P, McDermott DF, George S, Hammers HJ, Srinivas S, Tykodi SS, Sosman JA, Procopio G, Plimack ER, Castellano D, Gurney H, Donskov F, Peltola K, Wagstaff J, Gauler TC, Ueda T, Zhao H, Waxman IM, Motzer RJ, CheckMate i, (2017) CheckMate 025 Randomized phase 3 study: outcomes by key baseline factors and prior therapy for Nivolumab versus Everolimus in Advanced Renal Cell Carcinoma. Eur Urol 72(6):962-971. https://doi.org/10.1016/j.eururo.2017.02.010

14. Motzer RJ, Tannir NM, McDermott DF, Aren Frontera O, Melichar B, Choueiri TK, Plimack ER, Barthelemy P, Porta C, George S, Powles T, Donskov F, Neiman V, Kollmannsberger CK, Salman P, Gurney H, Hawkins R, Ravaud A, Grimm MO, Bracarda S, Barrios CH, Tomita Y, Castellano D, Rini BI, Chen AC, Mekan S, McHenry MB, Wind-Rotolo M, Doan J, Sharma P, Hammers HJ, Escudier B, CheckMate I (2018) Nivolumab plus Ipilimumab versus Sunitinib in Advanced Renal-Cell Carcinoma. N Engl J Med 378(14):1277-1290. https://doi.org/10.1056/NEJMoa1712 126

15. Motzer RJ, Rini BI, McDermott DF, Aren Frontera O, Hammers HJ, Carducci MA, Salman P, Escudier B, Beuselinck B, Amin A, Porta C, George S, Neiman V, Bracarda S, Tykodi SS, Barthelemy P, Leibowitz-Amit R, Plimack ER, Oosting SF, Redman B, Melichar B, Powles T, Nathan P, Oudard S, Pook D, Choueiri TK, Donskov F, Grimm MO, Gurney H, Heng DYC, Kollmannsberger CK, Harrison MR, Tomita Y, Duran I, Grunwald V, McHenry MB, Mekan S, Tannir NM, CheckMate i, (2019) Nivolumab plus ipilimumab versus sunitinib in first-line treatment for advanced renal cell carcinoma: extended follow-up of efficacy and safety results from a randomised, controlled, phase 3 trial. Lancet Oncol 20(10):1370-1385. https://doi.org/10.1016/S1470-2045(19)30413 $-9$

16. Motzer RJ, Penkov K, Haanen J, Rini B, Albiges L, Campbell MT, Venugopal B, Kollmannsberger C, Negrier S, Uemura M, Lee JL, Vasiliev A, Miller WH Jr, Gurney H, Schmidinger M, Larkin J, Atkins MB, Bedke J, Alekseev B, Wang J, Mariani M, Robbins PB, Chudnovsky A, Fowst C, Hariharan S, Huang B, di Pietro A, Choueiri TK (2019) Avelumab plus Axitinib versus Sunitinib for Advanced Renal-Cell Carcinoma. N Engl J Med 380(12):11031115. https://doi.org/10.1056/NEJMoa1816047

17. Rini BI, Plimack ER, Stus V, Gafanov R, Hawkins R, Nosov D, Pouliot F, Alekseev B, Soulieres D, Melichar B, Vynnychenko I, Kryzhanivska A, Bondarenko I, Azevedo SJ, Borchiellini D, Szczylik C, Markus M, McDermott RS, Bedke J, Tartas S, Chang YH, Tamada S, Shou Q, Perini RF, Chen M, Atkins MB, Powles T, Investigators K (2019) Pembrolizumab plus Axitinib versus Sunitinib for Advanced Renal-Cell Carcinoma. N Engl J Med 380(12):1116-1127. https://doi.org/10.1056/NEJMoa1816714

18. Concolino G, Marocchi A, Conti C, Tenaglia R, Di Silverio F, Bracci U (1978) Human renal cell carcinoma as a hormonedependent tumor. Cancer Res 38(11 Pt 2):4340-4344

19. Nosrati A, Tsai KK, Goldinger SM, Tumeh P, Grimes B, Loo K, Algazi AP, Nguyen-Kim TDL, Levesque M, Dummer R, Hamid O, Daud A (2017) Evaluation of clinicopathological factors in PD-1 response: derivation and validation of a prediction scale for response to PD-1 monotherapy. Br J Cancer 116(9):1141-1147. https://doi.org/10.1038/bjc.2017.70
20. Ozdemir BC, Dotto GP (2019) Sex Hormones and Anticancer Immunity. Clin Cancer Res 25(15):4603-4610. https://doi. org/10.1158/1078-0432.CCR-19-0137

21. Wallis CJD, Butaney M, Satkunasivam R, Freedland SJ, Patel SP, Hamid O, Pal SK, Klaassen Z (2019) Association of patient sex with efficacy of immune checkpoint inhibitors and overall survival in advanced cancers: a systematic review and meta-analysis. JAMA Oncol 5(4):529-536. https://doi.org/10.1001/jamao ncol.2018.5904

22. Yang F, Markovic SN, Molina JR, Halfdanarson TR, Pagliaro LC, Chintakuntlawar AV, Li R, Wei J, Wang L, Liu B, Nowakowski GS, Wang ML, Wang Y (2020) Association of sex, age, and eastern cooperative oncology group performance status with survival benefit of cancer immunotherapy in randomized clinical trials: a systematic review and meta-analysis. JAMA Netw Open 3(8):e2012534. https://doi.org/10.1001/jamanetworkopen .2020 .12534

23. Botticelli A, Onesti CE, Zizzari I, Cerbelli B, Sciattella P, Occhipinti M, Roberto M, Di Pietro F, Bonifacino A, Ghidini M, Vici P, Pizzuti L, Napoletano C, Strigari L, D’Amati G, Mazzuca F, Nuti M, Marchetti P (2017) The sexist behaviour of immune checkpoint inhibitors in cancer therapy? Oncotarget 8(59):99336-99346. https://doi.org/10.18632/oncotarget.22242

24. Conforti F, Pala L, Bagnardi V, De Pas T, Martinetti M, Viale G, Gelber RD, Goldhirsch A (2018) Cancer immunotherapy efficacy and patients' sex: a systematic review and meta-analysis. Lancet Oncol 19(6):737-746. https://doi.org/10.1016/S1470 -2045(18)30261-4

25. Mirandola L, Wade R, Verma R, Pena C, Hosiriluck N, Figueroa JA, Cobos E, Jenkins MR, Chiriva-Internati M (2015) Sexdriven differences in immunological responses: challenges and opportunities for the immunotherapies of the third millennium. Int Rev Immunol 34(2):134-142. https://doi.org/10.3109/08830 185.2015.1018417

26. Verthelyi $\mathrm{D}$ (2001) Sex hormones as immunomodulators in health and disease. Int Immunopharmacol 1(6):983-993. https://doi. org/10.1016/s1567-5769(01)00044-3

27. Kanda N, Tsuchida T, Tamaki K (1996) Testosterone inhibits immunoglobulin production by human peripheral blood mononuclear cells. Clin Exp Immunol 106(2):410-415. https://doi. org/10.1046/j.1365-2249.1996.d01-842.x

28. Roberts CW, Walker W, Alexander J (2001) Sex-associated hormones and immunity to protozoan parasites. Clin Microbiol Rev 14(3):476-488. https://doi.org/10.1128/CMR.14.3.476-488.2001

29. Polanczyk MJ, Hopke C, Vandenbark AA, Offner H (2006) Estrogen-mediated immunomodulation involves reduced activation of effector T cells, potentiation of Treg cells, and enhanced expression of the PD-1 costimulatory pathway. J Neurosci Res 84(2):370-378. https://doi.org/10.1002/jnr.20881

30. Salem ML (2004) Estrogen, a double-edged sword: modulation of TH1- and TH2-mediated inflammations by differential regulation of TH1/TH2 cytokine production. Curr Drug Targets Inflamm Allergy 3(1):97-104. https://doi.org/10.2174/1568010043483944

31. Long GV, Tykodi SS, Schneider JG, Garbe C, Gravis G, Rashford M, Agrawal S, Grigoryeva E, Bello A, Roy A, Rollin L, Zhao X (2018) Assessment of nivolumab exposure and clinical safety of $480 \mathrm{mg}$ every 4 weeks flat-dosing schedule in patients with cancer. Ann Oncol 29(11):2208-2213. https://doi.org/10.1093/annonc/ mdy 408

32. Heng DY, Xie W, Regan MM, Warren MA, Golshayan AR, Sahi C, Eigl BJ, Ruether JD, Cheng T, North S, Venner P, Knox JJ, Chi KN, Kollmannsberger C, McDermott DF, Oh WK, Atkins MB, Bukowski RM, Rini BI, Choueiri TK (2009) Prognostic factors for overall survival in patients with metastatic renal cell carcinoma treated with vascular endothelial growth factor-targeted agents: 
results from a large, multicenter study. J Clin Oncol 27(34):57945799. https://doi.org/10.1200/JCO.2008.21.4809

33. Eisenhauer EA, Therasse P, Bogaerts J, Schwartz LH, Sargent D, Ford R, Dancey J, Arbuck S, Gwyther S, Mooney M, Rubinstein L, Shankar L, Dodd L, Kaplan R, Lacombe D, Verweij J (2009) New response evaluation criteria in solid tumours: revised RECIST guideline (version 1.1). Eur J Cancer 45 (2):228-247. doi:https://doi.org/10.1016/j.ejca.2008.10.026

34. Klein SL, Flanagan KL (2016) Sex differences in immune responses. Nat Rev Immunol 16(10):626-638. https://doi. org/10.1038/nri.2016.90

35. Wang S, Cowley LA, Liu XS (2019) Sex Differences in Cancer Immunotherapy Efficacy, Biomarkers, and Therapeutic Strategy. Molecules 24 (18). doi:https://doi.org/10.3390/molecules241832 14

36. Pinto JA, Vallejos CS, Raez LE, Mas LA, Ruiz R, Torres-Roman JS, Morante Z, Araujo JM, Gomez HL, Aguilar A, Bretel D, Flores CJ, Rolfo C (2018) Gender and outcomes in non-small cell lung cancer: an old prognostic variable comes back for targeted therapy and immunotherapy? ESMO Open 3(3):e000344. https:// doi.org/10.1136/esmoopen-2018-000344

37. Graham J, Abdel-Rahman O, Choueiri TK, Heng DYC, International m RCCDC (2018) Re: Fabio Conforti, Laura Pala, Vincenzo Bagnardi, et al. Cancer Immunotherapy Efficacy and Patients' Sex: A Systematic Review and Meta-analysis. Lancet Oncol 2018;19:737-46: Outcomes of Metastatic Renal Cell Carcinoma by Gender: Contrasting Results from the International mRCC Database Consortium. Eur Urol 74 (6):e139-e140. doi:https:// doi.org/10.1016/j.eururo.2018.07.004

38. Wang C, Dehghani B, Li Y, Kaler LJ, Vandenbark AA, Offner H (2009) Oestrogen modulates experimental autoimmune encephalomyelitis and interleukin-17 production via programmed death 1. Immunology 126(3):329-335. https://doi.org/10.111 1/j.1365-2567.2008.03051.x

39. Shen Z, Rodriguez-Garcia M, Patel MV, Barr FD, Wira CR (2016) Menopausal status influences the expression of programmed death (PD)-1 and its ligand PD-L1 on immune cells from the human female reproductive tract. Am J Reprod Immunol 76(2):118-125. https://doi.org/10.1111/aji.12532

40. Guleria I, Khosroshahi A, Ansari MJ, Habicht A, Azuma M, Yagita H, Noelle RJ, Coyle A, Mellor AL, Khoury SJ, Sayegh MH (2005) A critical role for the programmed death ligand 1 in fetomaternal tolerance. J Exp Med 202(2):231-237. https://doi. org/10.1084/jem.20050019

41. Song W, He D, Chen Y, Yeh CR, Hsu I, Huang Q, Zhang X, Chang LS, Zuo L, Chen J, Doersch KM, Chang C, Li L, Yeh S (2018) Targeting newly identified ERbeta/TGF-beta1/SMAD3 signals with the FDA-approved anti-estrogen Faslodex or an ERbeta selective antagonist in renal cell carcinoma. Mol Oncol 12(12):2055-2071. https://doi.org/10.1002/1878-0261.12377

42. Kabat GC, Silvera SA, Miller AB, Rohan TE (2007) A cohort study of reproductive and hormonal factors and renal cell cancer risk in women. Br J Cancer 96(5):845-849. https://doi. org/10.1038/sj.bjc.6603629

43. Tsukamoto H, Fujieda K, Miyashita A, Fukushima S, Ikeda T, Kubo Y, Senju S, Ihn H, Nishimura Y, Oshiumi H (2018) Combined blockade of IL6 and PD-1/PD-L1 Signaling Abrogates mutual regulation of their immunosuppressive effects in the tumor microenvironment. Cancer Res 78(17):5011-5022. https://doi. org/10.1158/0008-5472.CAN-18-0118
44. Purohit A, Newman SP, Reed MJ (2002) The role of cytokines in regulating estrogen synthesis: implications for the etiology of breast cancer. Breast Cancer Res 4(2):65-69. https://doi. org/10.1186/bcr425

45. Yang L, Huang F, Mei J, Wang X, Zhang Q, Wang H, Xi M, You Z (2017) Posttranscriptional Control of PD-L1 Expression by 17 beta-Estradiol via PI3K/Akt Signaling Pathway in ERalphaPositive Cancer Cell Lines. Int J Gynecol Cancer 27(2):196-205. https://doi.org/10.1097/IGC.0000000000000875

46. Niikawa H, Suzuki T, Miki Y, Suzuki S, Nagasaki S, Akahira J, Honma S, Evans DB, Hayashi S, Kondo T, Sasano H (2008) Intratumoral estrogens and estrogen receptors in human non-small cell lung carcinoma. Clin Cancer Res 14(14):4417-4426. https:// doi.org/10.1158/1078-0432.CCR-07-1950

47. Mah V, Marquez D, Alavi M, Maresh EL, Zhang L, Yoon N, Horvath S, Bagryanova L, Fishbein MC, Chia D, Pietras R, Goodglick L (2011) Expression levels of estrogen receptor beta in conjunction with aromatase predict survival in non-small cell lung cancer. Lung Cancer 74(2):318-325. https://doi.org/10.1016/j.lungc an.2011.03.009

48. Guercio G, Saraco N, Costanzo M, Marino R, Ramirez P, Berensztein E, Rivarola MA, Belgorosky A (2020) Estrogens in human male gonadotropin secretion and testicular physiology from infancy to late puberty. Front Endocrinol (Lausanne) 11:72. https ://doi.org/10.3389/fendo.2020.00072

49. Hayes FJ, Seminara SB, Decruz S, Boepple PA, Crowley WF Jr (2000) Aromatase inhibition in the human male reveals a hypothalamic site of estrogen feedback. J Clin Endocrinol Metab 85(9):3027-3035. https://doi.org/10.1210/jcem.85.9.6795

50. Qu Y, Chen H, Gu W, Gu C, Zhang H, Xu J, Zhu Y, Ye D (2015) Age-dependent association between sex and renal cell carcinoma mortality: a population-based analysis. Sci Rep 5:9160. https:// doi.org/10.1038/srep09160

51. Sun L, Gao Z, Luo L, Tan H, Zhang G (2018) Estrogen affects cell growth and IGF-1 receptor expression in renal cell carcinoma. Onco Targets Ther 11:5873-5878. https://doi.org/10.2147/OTT. S172149

52. Harris DT (1983) Hormonal therapy and chemotherapy of renalcell carcinoma. Semin Oncol 10(4):422-430

53. Lee CP, Patel PM, Selby PJ, Hancock BW, Mak I, Pyle L, James MG, Beirne DA, Steeds S, A'Hern R, Gore ME, Eisen T (2006) Randomized phase II study comparing thalidomide with medroxyprogesterone acetate in patients with metastatic renal cell carcinoma. J Clin Oncol 24(6):898-903. https://doi.org/10.1200/ JCO.2005.03.7309

54. Yu CP, Ho JY, Huang YT, Cha TL, Sun GH, Yu DS, Chang FW, Chen SP, Hsu RJ (2013) Estrogen inhibits renal cell carcinoma cell progression through estrogen receptor-beta activation. PLoS ONE 8(2):e56667. https://doi.org/10.1371/journal.pone.0056667

55. von Allmen RS, Weiss S, Tevaearai HT, Kuemmerli C, Tinner C, Carrel TP, Schmidli J, Dick F (2015) Completeness of followup determines validity of study findings: results of a prospective repeated measures cohort study. PLoS ONE 10(10):e0140817. https://doi.org/10.1371/journal.pone.0140817

Publisher's Note Springer Nature remains neutral with regard to jurisdictional claims in published maps and institutional affiliations. 